\title{
Bariery rozwoju przedsiębiorczości w Polsce
}

https://doi.org/10.33141/po.2005.05.04

\section{Aleksandra Gaweł}

Przegląd Organizacji, Nr 5 (784), 2005, ss. 16-19 www.przegladorganizacji.pl Towarzystwo Naukowe Organizacji i Kierownictwa (TNOiK)

\section{Wprowadzenie}

W prezentowanym tekście przedstawiono wyniki badań mających za zadanie określenie barier najistotniejszych dla rozwoju przedsiębiorczości w Polsce. Badanie przeprowadzono na podstawie wskaźników jakościowych testu koniunkturalnego. Wskaźniki jakościowe są generowane na podstawie odpowiedzi przedsiębiorstw na cokwartalna ankietę, w której wskazują najsilniej ograniczające je bariery. Spośród dziesięciu wyodrębnionych barier, w kształtowaniu się przedsiębiorczości najistotniejsze okazały się dwie: konkurencyjny import i wysokie obciążenia podatkowe.

\section{Próba definicji przedsiębiorczości}

W spółcześnie można spotkać się z trzema podejściami do przedsiębiorczości, wynikającymi z różnych dziedzin nauki. Podejście wypływające z nauk ekonomicznych kładzie akcent na określeniu roli przedsiębiorcy w rozwoju ekonomicznym w skali przedsiębiorstwa i społeczeństwa. Szkoła psychologiczna podchodzi do przedsiębiorczości od strony osobowości przedsiębiorcy i cech charakteru sprzyjajacych osiaganiu przez niego sukcesu lub porażki. Natomiast $\mathrm{w}$ ramach ujęcia socjologicznego określa się wpływ otoczenia socjologicznego na podejmowanie aktywności przedsiębiorczej (Deakins, Freel, 2003).

Teoria ekonomii widzi przedsiębiorcę w kilku rolach. Przedsiębiorca jest organizatorem czynników produkcji zgodnie z poglądami Saya, Cantillona, ułatwia wymianę poprzez zdolność do wykorzystania możliwości rynkowych w ujęciu Kirznera, jest innowatorem według Schumpetera, ponosi ryzyko zgodnie z poglądami Knighta, organizuje zasoby według Cassona czy wreszcie jest kreatywny w ujęciu Shackle'a (Deakins, Freel, 2003). Przez długi czas przedsiębiorca był postrzegany jako osoba znajdująca się na szczycie hierarchii społecznej, która determinuje zachowanie firm i ponosi odpowiedzialność za żywotność gospodarki. Choć w pismach klasycznych pojawiał się często, brakowało mu zdefiniowanej formy i funkcji. Najsilniejszy wpływ na badania nad przedsiębiorczością wywarły prace Josepha Schumpetera i Franka Knighta, w których rozpoczęto analizę obszarów działalności, w których ważna jest postawa przedsiębiorcy (Baumol, 1968). Stąd też współczesne badania naukowe dotyczące przedsiębiorczości prowadzone są w dwóch głównych nurtach. Pierwszy z nich wywodzi się z prac teoretycznych Franka Knighta z lat 20. ub. wieku, w których główny akcent został postawiony na zdolności przedsiębiorców do ponoszenia ryzyka. Drugi nurt teoretyczny początek swój bierze z prac Josepha Schumpetera z lat 30., w których z kolei podkreśla się zdolność przedsiębiorców do tworzenia nowych produktów, idei, rynków, technologii itp., zatem przedsiębiorca jest innowatorem, choć nie jest to równoznaczne z ponoszeniem ryzyka (Schumpeter, 1960).

Szkoła psychologiczna myślenia o przedsiębiorcy wskazuje na cechy jego osobowości, które sprzyjaja osiąganiu przez niego sukcesu. Wśród czynników sukcesu wymienia się osobowość przedsiębiorczą, aktywność, czyli inicjatywę i asertywność, orientację na osiągnięcia, pasję, upór w pokonywaniu niepowodzeń, zaufanie do swoich zdolności i koncepcji biznesu, determinację, zarządzanie ryzykiem, postrzeganie zmian jako możliwości, tolerancję dla nie uporządkowanego życia, perfekcjonizm, niecierpliwość, kreatywność czy też motywację. Natomiast szkoła socjologiczna wskazuje głównie na czynniki zewnętrzne, które oddziałują na przedsiębiorczość, do których zalicza się czynniki kulturowe czy okoliczności związane ze społeczeństwem, np. wykluczenie z rynku pracy (Deakins, Freel, 2003).

We współczesnej ekonomii można spotkać się z propozycjami definicji przedsiębiorcy jako osoby, która jest pomysłowa i kreatywna w szukaniu sposobów, by zwiększyć swoje bogactwo, siłę i prestiż (Baumol, 1990), a przedsiębiorczości jako kombinacji indywidualnych, specyficznych zdolności ludzi do generowania niepewnych zwrotów z inwestycji (Gentry, Hubbard, 2000).

W badaniach nad przedsiębiorczością i potocznym jej rozumieniem najczęściej przedsiębiorcę utożsamia się z osobą prowadzącą na własny rachunek firmę, a zatem z samozatrudnionym, który podejmuje ryzyko niepewnego zysku zamiast pewności wynagrodzenia za pracę najemną, a konkurencja rynkowa wymusza wprowadzanie coraz to nowych rozwiązań organizacyjnych czy produktowych. Takie spojrzenie zostaje również potwierdzone przez analizę cech osób prowadzacych przedsiębiorstwo na własny rachunek, wśród których wymienia się skłonność do podejmowania ryzyka, nowatorstwo, inicjatywę, oryginalność, silną motywację osiągnięć, uznanie dla pracy, zysku i prywatnej własności jako źródeł bogactwa jednostki i społeczeństwa (Targalski, 1997), zatem cechy przypisywane przedsiębiorcom.

Przedsiębiorca bywa również utożsamiany z kapitalistą, czyli osobą angażującą własny kapitał w aktywność gospodarczą. Takie myślenie jest zawarte w modelach przedsiębiorczości opartych na ogranicze- 
niach płynności (np. Holtz - Eakin, Joulfaian, Rosen, 1994; Evans, Jovanovic, 1989). Ze względu na niedoskonałości rynku kapitałowego i asymetrię informacji, nie wszystkie przedsięwzięcia mogą liczyć na takie wsparcie finansowe instytucji pożyczkowych, które pozwoliłoby realizować maksymalny zysk. Stąd też osoby planujace działalność sa zmuszone do zaangażowania własnych środków finansowych, a przedsiębiorca zostaje ten, kto posiada majątek niezbędny do prowadzenia działalności.

Inne wyjaśnienie przyczyn łączenia funkcji przedsiębiorcy i kapitalisty wypływa z występujących współcześnie ograniczeń odpowiedzialności. Można przyjąć, że osoby posiadające majątek stoją przed wyborem samodzielnego wykorzystania własnego kapitału do prowadzenia własnej firmy lub udzielenia pożyczki innym. Przy ograniczonej odpowiedzialności w razie utraty kapitału przez potencjalnych pożyczkobiorców i występującym hazardzie moralnym, pożyczkobiorcy zachowują się w sposób bardziej ryzykowny, co zwiększa ryzyko utraty kapitału, jakie ponosi pożyczkodawca. W związku z tym, osoby posiadajace określone zasoby finansowe preferuja samodzielne nadzorowanie jego użycia niż udzielanie pożyczek innym. Dzięki temu zmniejsza się prawdopodobieństwo utraty przez nich kapitału, a jednocześnie czyni z nich przedsiębiorców (Eswaran, Kotwal, 1989).

Z kolei prace wypływające $\mathrm{z}$ inspiracji myślenia Schumpeteriańskiego, widzą istotę przedsiębiorcy w jego zdolności do tworzenia innowacji w postaci nowych produktów czy usług, nowych rynków zbytu, nowych rozwiązań technologicznych czy nowych form organizacji przedsiębiorstwa czy przemysłu. W takim ujęciu przedsiębiorca jest twórcą, który jednak nie musi ponosić ryzyka niepowodzenia, nie musi ponosić nakładów finansowych, a swoje zdolności przedsiębiorcze może lokować zarówno jako pracownik najemny, będąc przykładem przedsiębiorczości wewnętrznej (intrapreneurship), lub w ramach samodzielnie prowadzonej firmy, stajac się przykładem przedsiębiorczości zewnętrznej (entrepreneurship). Przykładowo, na przedsiębiorczości rozumianej jako zdolność innowacyjna bazują firmy typu venture capital, które oferuja wsparcie kapitałowe czy doradcze, finansując innowacyjne przedsięwzięcia dostarczające nowości rynkowych (Keuschnigg, Nielsen, 2000, 2001). Spółki te biora na siebie ryzyko niepowodzenia i inwestycje kapitałowe, natomiast przedsiębiorca wnosi do wspólnej inicjatywy pomysł innowacyjny. Badania empiryczne nad przetrwaniem nowo powstających firm udowadniaja, że aktywność innowacyjna małych firm jest czynnikiem promujacym ich przeżycie (Audretsch, 1991).

Na decyzje o podjęciu działań przedsiębiorczych wpływają również czynniki związane z poziomem rozwoju gospodarczego oraz polityką makroekonomiczną i przemysłową (Morawski, Socha, 2003).

Coraz częściej badania nad istota przedsiębiorczości, oprócz koncentracji na osobie przedsiębiorcy jako takiej, rozszerzają zakres swoich zainteresowań o proces przedsiębiorczy. Zatem, obok wskazania kto i dlaczego zostaje przedsiębiorcą oraz cech osobowych przyczyniających się do sukcesu lub porażki przedsiębiorczej, bada się proces związany z wprowadzeniem nowych produktów i nowych rozwiązań organizacyjnych na rynek. Stąd w zrewidowanej definicji przedsiębiorczości istotne jest określenie czynników, które umożliwiają dostrzeżenie nowych i efektywnych możliwości rynkowych, kluczowych zadań koniecznych do stworzenia nowej organizacji sukcesu, różnic między zadaniami spełnianymi w organizacjach już istniejących i nowo tworzonych oraz roli przedsiębiorcy w procesie przedsiębiorczym (Bygrave, Hofer, 1991).

Mimo wątpliwości definicyjnych pragmatyka prowadzenia badań nad przedsiębiorczością wskazuje, że najczęściej w analizach empirycznych przedsiębiorców utożsamia się z samozatrudnionymi, a stopę przedsiębiorczości wyznacza się jako udział samozatrudnionych w liczbie ludności w wieku produkcyjnym, w zasobie pracy lub w liczbie pracujacych (m.in. Blanchflower, 2000; Ilmakunnas, Kanniainen, 2001).

\section{Bariery ograniczające rozwój przedsiębiorczości na przykładzie Polski}

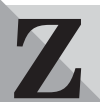

uwagi na znaczenie przedsiębiorczości dla sytuacji gospodarczej kraju i funkcjonowania firm, przeprowadzono analizę barier ograniczających jej rozwój. Z powodu dostępności danych, badanie ograniczono do analizy sytuacji w przemyśle przetwórczym. W badaniu uwzględniono dane kwartalne za okres od I kw. 1993 do IV kw. 2003 r.

Przyjęto, że miarą przedsiębiorczości jest liczba osób samozatrudnionych w przemyśle przetwórczym, które pracują na własny rachunek. Dane dotyczace kształtowania się ich liczby zaczerpnięto z kwartalnika „Aktywność Ekonomiczna Ludności Polski”, wydawanego przez Główny Urząd Statystyczny w Warszawie za lata 1993-2003.

Natomiast do analizy informacji o barierach rozwoju firm zostały wykorzystane wskaźniki prezentowane w kwartalniku „Badania Koniunktury”, wydawanego przez Główny Urząd Statystyczny w Warszawie za lata 1993-2003. Dane dotyczace barier rozwoju firm są wskaźnikami jakościowymi, generowanymi na podstawie odpowiedzi ankietowych przedsiębiorstw. Dane jakościowe, zwane również wskaźnikami testu koniunkturalnego, stanowią alternatywę dla danych ilościowych oceny stanu gospodarki. Ich istota polega na tym, że sa tworzone na podstawie subiektywnych ocen sytuacji ekonomicznej dokonywanych systematycznie przez podmioty gospodarcze. Zawierają zatem w sobie inną zawartość informacyjną niż dane ilościowe. Przesłanką metodologiczną tworzenia wskaźników jakościowych jest założenie, że na kształtowanie się procesów ekonomicznych wpływają psychologiczne aspekty decyzji gospodarczych podejmowanych przez podmioty, które powodują zmienność ich zachowań w czasie (Rekowski, 1997).

Wyniki testu koniunkturalnego sa generowane na podstawie odpowiedzi podmiotów gospodarczych na comiesięczną lub cokwartalną ankietę, w której przedsiębiorstwa określają, czy dana kategoria, np. ich ogólna sytuacja ekonomiczna czy zdolność do regulowania zobowiązań finansowych, poprawiła się, pogorszyła czy pozostała bez zmian. Wartość danego wskaźnika stanowi różnicę między procentową liczbą odpowiedzi wskazujących na poprawę danej wielkości ekonomicznej a odpowiedziami pokazującymi jej pogorszenie się. Wskaźniki jakościowe można podzielić na dane diagno- 
styczne, oceniające bieżącą sytuację, dane prognostyczne, wskazujące na oczekiwania respondentów co do kształtu przyszłych zjawisk i wskaźniki złożone, zwane również klimatami, które stanowią średnią ze wskaźników diagnostycznych i prognostycznych.

Wskaźniki jakościowe dotyczące barier są zbierane w układzie kwartalnym i maja charakter wskaźników diagnostycznych, oceniających bieżącą sytuację. W wypełnianej ankiecie przedsiębiorstwa wskazują te bariery, które w najistotniejszy sposób ograniczają ich rozwój. Wartość wskaźnika wynika z procentowego udziału odpowiedzi wskazujących na dane zjawisko jako barierę prowadzenia działalności w całej zbiorowości odpowiedzi. Wzrost wartości danego wskaźnika obrazującego barierę należy interpretować jako konsekwencję rosnącej liczby przedsiębiorstw wskazujących w swoich odpowiedziach na tę barierę jako czynnik ograniczający ich działalność. Wskaźniki jakościowe prezentujące bariery działalności gospodarczej przedsiębiorstw mogą zatem przyjmować wartości z przedziału od (0), gdy żaden z respondentów nie wskaże na dany czynnik jako barierę, do (100), gdy wszyscy ankietowani uznają dane zjawisko za barierę swojego rozwoju.

W szczególności następujące bariery ograniczające rozwój przedsiębiorstw zostały uwzględnione w prezentowanym badaniu:

- brak barier,

- niedostateczny popyt krajowy,

- niedostateczny popyt zagraniczny,

- konkurencyjny import

- brak wykwalifikowanej kadry pracowniczej,

- niedobory surowców, materiałów i półfabrykatów z przyczyn pozafinansowych,

- wysokie obciążenia podatkowe,

- brak odpowiedniego parku maszynowego,

- niejasne i niespójne przepisy prawne,

- inne bariery.

Ponieważ rozwój przedsiębiorczości jest związany z sektorem małych i średnich firm, a przeciętny polski przedsiębiorca należy do tego sektora, w badaniu uwzględniono odpowiedzi ankietowe przedsiębiorstw małych, zatrudniających od 10 do 49 pracowników.

W badaniu wpływu barier ekonomicznych na rozwój przedsiębiorczości w pierwszej kolejności dokonano dekompozycji sezonowej, w ramach której oczyszczono surowe wskaźniki z wpływu wahań przypadkowych i sezonowych. W tym celu zastosowano procedurę dekompozycyjna Census dla danych kwartalnych.

Następnie, w celu identyfikacji barier rozwoju przedsiębiorczości, zastosowano metodę regresji. Zmienną zależna, wyjaśnianą poprzez funkcję regresji, była liczba przedsiębiorców działających w prze- myśle przetwórczym. Natomiast zmiennymi niezależnymi, które objaśniają kształtowanie się przedsiębiorczości, były wskaźniki jakościowe prezentujące bariery działalności gospodarczej. Początkowo przy tworzeniu funkcji regresji uwzględniono wszystkie możliwe bariery, zatem wstępna postać funkcji regresji była przedstawiona w ogólnym równaniu (1).

$$
\begin{gathered}
P P P=a_{0}+a_{1} B B+a_{2} P K+a_{3} P Z+a_{4} K I+ \\
+a_{5} W P+a_{6} B S+a_{7} O P+a_{8} P M+a_{9} P P+a_{10} I
\end{gathered}
$$

gdzie: PPP - liczba przedsiębiorców w przemyśle przetwórczym, BB - wskaźnik braku barier, PK - wskaźnik bariery niewystarczającego popytu krajowego, PZ - wskaźnik bariery niewystarczającego popytu zagranicznego, KI - wskaźnik bariery konkurencyjnego importu, WP - wskaźnik bariery braku wykwalifikowanej kadry, BS - wskaźnik braku surowców z powodów pozafinansowych, OP - wskaźnik bariery wysokich obciążeń podatkowych, PM - wskaźnik bariery braku odpowiedniego parku maszynowego, PP wskaźnik bariery niejasnych i niespójnych przepisów prawnych, I - wskaźnik innych barier, $\mathrm{a}_{0}, \mathrm{a}_{1}, \mathrm{a}_{2}, \mathrm{a}_{3}, \mathrm{a}_{4}$, $\mathrm{a}_{5}, \mathrm{a}_{6}, \mathrm{a}_{7}, \mathrm{a}_{8}, \mathrm{a}_{9}, \mathrm{a}_{10}-$ parametry równania.

Po początkowym uwzględnieniu wszystkich barier $\mathrm{w}$ budowaniu funkcji regresji, z równania usuwano te zmienne, które były nieistotne ze statystycznego punktu widzenia. Za kryterium usuwania lub akceptowania zmiennych niezależnych przyjęto poziom istotności. W konsekwencji uzyskano funkcję o postaci (2).

$$
\mathrm{PPP}=523,3-4,5 \mathrm{KI}-3,6 \mathrm{OP}
$$

Oznacza to, że w kształtowaniu się przedsiębiorczości istotne okazały się dwie bariery: konkurencyjny import i wysokie obciążenia podatkowe. Negatywne wartości parametrów funkcji przy tych zmiennych wskazują na odwrotnie proporcjonalną zależność między nimi a przedsiębiorczością. Rosnące bariery konkurencyjnego importu i obciążeń podatkowych przyczyniają się do spadku przedsiębiorczości. Natomiast malejąca uciążliwość tych bariery stanowi przyczynę wzrostu liczby przedsiębiorców.

Jakość dopasowania funkcji (2) została przedstawiona w tabeli. Na podstawie skorygowanego współczynnika determinacji, który przyjął wartość $(0,6997)$, można sądzić, że bariery konkurencyjnego importu i wysokich obciążeń podatkowych w $70 \%$ objaśniają zmiany w liczbie przedsiębiorców. Można zatem uznać, że funkcja dobrze opisuje zmienną zależną.

Stopień dopasowania funkcji regresji można dodatkowo potwierdzić poprzez analizę graficzną kształtowania się liczby przedsiębiorców i ich modelu zbudo-

Tab. Podsumowanie funkcji regresji liczby przedsiębiorców

\begin{tabular}{|l|l|c|c|c|c|}
\hline \multicolumn{1}{|c|}{ Oceny funkcji regresji } & \multicolumn{5}{c|}{ Oceny parametrów funkcji regresji } \\
\hline $\begin{array}{l}-\mathrm{R}=0,84479963 \\
-\mathrm{R}^{2}=0,71368641\end{array}$ & $\begin{array}{c}\text { Nazwa } \\
\text { parametru }\end{array}$ & $\begin{array}{c}\text { Wartość } \\
\text { parametru }\end{array}$ & $\begin{array}{c}\text { Błąd } \\
\text { standardowy } \\
\text { parametru }\end{array}$ & t (41) & $\begin{array}{c}\text { Poziom } \\
\text { istotności }\end{array}$ \\
\cline { 2 - 6 } $\begin{array}{l}\mathrm{F}(2,41)=51,1 \\
- \text { Błąd standardowy estymacji: } 13,738\end{array}$ & Wyraz wolny & 523,2627 & 35,48319 & 14,74678 & 0 \\
\cline { 2 - 7 } & KI & $-4,47712$ & 1,107669 & $-4,04193$ & 0,000228 \\
\cline { 2 - 6 } & OP & $-3,62193$ & 0,369878 & $-9,79224$ & 0 \\
\hline
\end{tabular}

Źródło: opracowanie własne. 


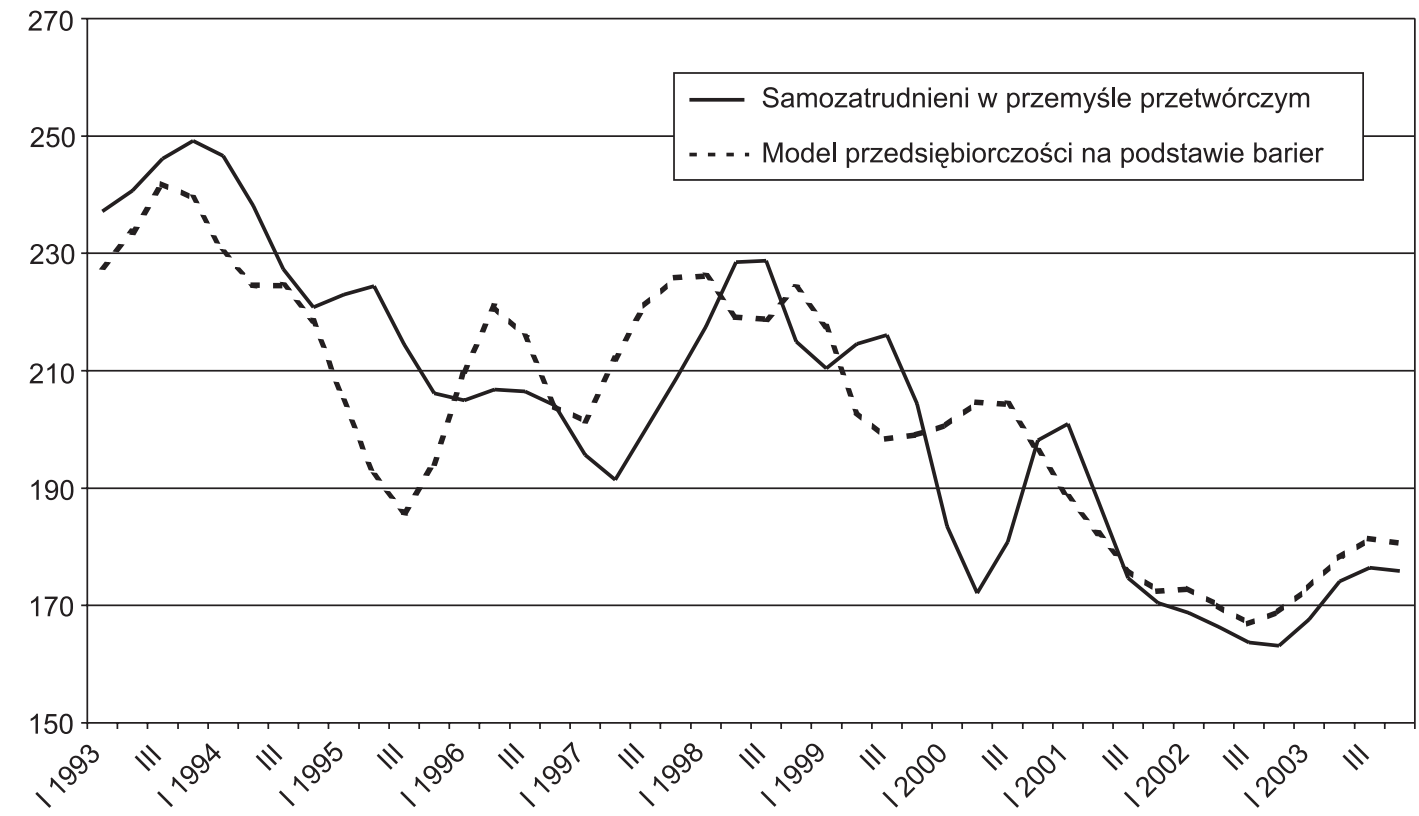

Wykres. Kształtowanie się liczby przedsiębiorców w przemyśle przetwórczym i modelu zbudowanego na podstawie barier rozwoju przedsiębiorstw

Źródło: opracowanie własne.

wanego na podstawie barier, które są przedstawione na wykresie.

Przeprowadzone badanie pozwoliło stwierdzić, że wśród dziesięciu analizowanych barier, największy wpływ na kształtowanie się przedsiębiorczości miały dwie: konkurencyjnego importu i wysokich obciążeń podatkowych. Ich wpływ na przedsiębiorczość był odwrotnie proporcjonalny. Wzrost tych barier przyczyniał się do spadku liczby przedsiębiorców w przemyśle przetwórczym. Stąd kształtowanie polityki gospodarczej, sprzyjającej kreowaniu przedsiębiorczości w społeczeństwie, powinno zmierzać do ograniczania utrudnień w prowadzeniu działalności gospodarczej w tych aspektach.

\section{dr Aleksandra Gawet} Akademia Ekonomiczna w Poznaniu Katedra Mikroekonomii

\section{BIBLIOGRAFIA}

[1] Aktywność Ekonomiczna Ludności Polski, Główny Urząd Statystyczny w Warszawie, roczniki za lata 1993-2003.

[2] AUDRETSCH D.B. (1991), New-Firm Survival and the Technological Regime, „The Review of Economics and Statistics", vol. LXXIII, s. 441-450.

[3] Badania Koniunktury, Główny Urząd Statystyczny w Warszawie, roczniki za lata 1993-2003.

[4] BATES T. (1985), Entrepreneur Human Capital Endowments and Minority Business Viability, „The Journal of Human Resources", s. 540-554.

[5] BATES T. (1990), Entrepreneur Human Capital Inputs and Small Business Longevity, „The Review of Economics and Statistics", s. 551-559.

[6] BAUMOL W.J. (1968), Entrepreneurship in Economic Theory, „The American Economic Review”, s. 64-71.

[7] BAUMOL W.J. (1990), Entrepreneurship: Productive, Unproductive, and Destructive, „Journal of Political Economy", vol. 98, s. 893-921.

[8] BLANCHFLOWER D. G. (2000), Self-Employment in OECD Countries, „NBER Working Paper” nr 7486.

[9] BYGRAVE W.D., HOFER Ch.W. (1991), Theorizing About Entrepreneurship, „Entrepreneurship Theory and Practice", wiosna.
[10] CRESSY R. (1996), Are Business Startups Debt - Rationed?, „The Economic Journal”.

[11] DEAKINS D., FREEL M. (2003), Entrepreneurship and Small Firms, McGraw Hill Education, edycja 3.

[12] ESWARAN M., KOTWAL A. (1989), Why Are Capitalists the Boses?, „The Economic Journal”, vol. 99, s. 164-176. [13] EVANS D.S., JOVANOVIC B. (1989), An Estimated Model of Entrepreneurial Choice under Liquidity Constraints, „Journal of Political Economy”, s. 808-827.

[14] GENTRY W.M., HUBBARD R.G. (2000), Tax Policy and Entrepreneurial Entry, „The American Economic Review", vol. 90 , s. $283-287$.

[15] HOLTZ-EAKIN D., JOULAIAN D., ROSEN H.S (1994), Sticking It Out: Entrepreneurial Survival and Liquidity Constraints, „Journal of Political Economy”, vol. 102, s. 53-75.

[16] ILMAKUNNAS P., KANNIAINEN V. (2001), Entrepreneurship, Economic Risks, and Risk Insurance in the Welfare State: Results with OECD Data 1978-93, „German Economic Review", vol. 2, sierpień.

[17] KEUSCHNIGG Ch., NIELSEN S.B. (2000), Tax Policy, Venture Capital, and Entrepreneurship, „NBER Working Paper" nr 7976.

[18] KEUSCHNIGG Ch., NIELSEN S.B. (2001), Public Policy for Venture Capital, „CESifo Working Paper” nr 486.

[19] MORAWSKI L., SOCHA M.W. (2003), Different Paths to Non-agricultural Self-Employment? Evidence from Poland, Germany and the United Kingdom, „Emergo”, vol. 10, nr $1(35)$, s. $14-29$.

[20] OTANI K. (1996), A Human Capital Approach to Entrepreneurial Capacity, „Economica”.

[21] PIATIER A. (1979), Business Cycle Surveys. Their Utilization for Forecasting, Selected papers of $14^{\text {th }}$ CIRET conference; Lisbon, red. W.H. STRIGEL, München: IFO.

[22] REKOWSKI M. (1997), Test koniunkturalny - istota, konstrukcja, zakres zastosowań, [w:] Koniunktura gospodarcza Polski. Analiza grup produktowych, red. M. Rekowski, Wydawnictwo Akademia, Poznań.

[23] ROMER D. (2000), Makroekonomia dla zaawansowanych, Wydawnictwo Naukowe PWN, Warszawa.

[24] SCHUMPETER J. (1960), Teoria rozwoju gospodarczego, PWN, Warszawa.

[25] TARGALSKI J. (1997), Szanse rozwoju przedsiębiorczości, „Zeszyty Naukowe Akademii Ekonomicznej w Krakowie", nr 473, s. 5-9. 